\title{
Pooled subsidence records from numerous wells reveal variations in pre-breakup rifting along the proximal domains of the Iberia-Newfoundland continental margins
}

\begin{tabular}{|r|l|}
\hline Journal: & Geological Magazine \\
\hline Manuscript ID & GEO-17-1916.R2 \\
\hline Manuscript Type: & Original Article \\
\hline Date Submitted by the Author: & 22-Aug-2018 \\
\hline Complete List of Authors: & $\begin{array}{l}\text { Spooner, Cameron; University of Aberdeen, School of Geosciencs; } \\
\text { Stephenson, Randell; University of Aberdeen, School of Geosciencs } \\
\text { Butler, Rob; University of Aberdeen, Department of Geology \& Petroleum } \\
\text { Geology; }\end{array}$ \\
\hline Keywords: & North, Atlantic, Mesozoic, tectonic, backstripped, conjugate, trends \\
\hline & \\
\hline
\end{tabular}




\section{Pooled subsidence records from numerous wells reveal}

2 variations in pre-breakup rifting along the proximal domains of

3 the Iberia-Newfoundland continental margins

4 Original article

$5 \quad$ Running header - Iberia-Newfoundland proximal subsidence curves

6 Cameron Spooner $^{1 \mathrm{a}}$, Randell Stephenson ${ }^{1}$, Robert W.H. Butler ${ }^{1}$

$7 \quad{ }^{1}$ Geology and Petroleum Geology, School of Geosciences, King's College, University of

8 Aberdeen, Aberdeen, AB24 3UE, UK.

$9 \quad{ }^{\mathrm{a} C}$ C.Spooner.12@aberdeen.ac.uk

10

11

12

13

14

15

16

17

18

19

20

21

22 


\section{ABSTRACT}

24 The Iberia-Newfoundland continental margin is one of the most studied conjugate margins in the

25 world. However, many unknowns remain regarding the nature of rifting preceding its breakup.

26 Here a large dataset of tectonic subsidence curves, created from publicly available well data, is

27 analysed to show spatial and temporal trends of rifting in the proximal domains of the margin. A

28 novel methodology of bulk averaging tectonic subsidence curves is developed that can be

29 applied on any conjugate margin with a similar spread of well data. The method does not rely on

30 the existence of conjugate, deep seismic profiles and specifically attempts to forego the risk of

31 quantitative bias derived from localised anomalies and uncertain stratigraphic dating and

32 correlation. Results for the Iberia-Newfoundland margin show active rift-driven tectonic

33 subsidence occurred in the Central segment of the conjugate margin from $\sim 227 \mathrm{Ma}$ (start Norian)

34 to $\sim 152.1 \mathrm{Ma}$ (start Tithonian); in the Southern segment from $\sim 208.5 \mathrm{Ma}$ (start Rhaetian) to

$35 \sim 152.1 \mathrm{Ma}$ (start Tithonian); and in the Northern segment from $\sim 201.3 \mathrm{Ma}$ (start Hettangian) to

$36 \sim 132.9 \mathrm{Ma}$ (start Hauterivian). This indicates that rifting in the stretching phase of the proximal

37 domain of the Iberia-Newfoundland margin does not mirror hyperextended domain rifting trends

38 (South to North) that ultimately led to breakup. The insights into broad scale three dimensional

39 spatial and temporal trends, produced using the novel methodology presented in this paper,

40 provide added value for interpretation of the development of passive margins, and new

41 constraints for modelling of the formation of conjugate margins.

42 (Keywords: North, Atlantic, Mesozoic, tectonic, backstripping, conjugate, trends)

43

44

45 


\section{INTRODUCTION}

47 The aim of this paper is to introduce a new method for increasing the utility of spatially diverse,

48 but incomplete well-data, in investigating subsidence and its spatial variability on rifted

49 continental margins. We use the much-studied Newfoundland-Iberia conjugate margins of the

50 Atlantic to illustrate our approach.

51 Subsidence in sedimentary basins, recorded by the stratigraphy of the basin fill, is primary

52 evidence for deducing the tectonic processes by which continents rift. This has been quantified

53 using well-data since pioneering studies at continental margins (e.g. Steckler and Watts, 1978)

54 and in intracontinental settings (Barton and Wood, 1984). However, many studies that use

55 boreholes to calculate subsidence histories focus on those few wells that have the appropriate

56 combination of stratigraphic thicknesses, compaction criteria, depositional ages,

57 palaeobathymetry, known eustatic sea-level signals and denudation histories across

58 unconformities or instead rely upon the creation of synthetic wells.

59 Building subsidence records from only a few wells risks introducing significant sample bias to

60 studies if the studied wells are not representative of the variability in depositional/subsidence

61 history of the study area. This type of bias can sometimes be mitigated by backstripping 2D

62 geological interpretations on cross-sections (e.g. Steckler et al., 1999) or even 3D volumes using

63 well-calibrated seismic data (e.g. Hansen et al., 2007). However, 1D well data and the

64 subsidence they record are still commonly used in frontier areas where seismic data are of

65 insufficient quality for 2D or 3D analysis. Recent studies have focused on those wells that

66 conform to high standards of high-quality stratigraphic data, or on a few "pseudo-wells" built

67 from sparse seismic profiles (e.g. Alves and Cunha, 2018). Those wells that do not conform to

68 these standards are neglected. The effect is to restrict spatial resolution for subsidence studies 
69 that risks obscuring lateral variations in subsidence rate and timing along rifted continental

70 margins.

71 Restricting analysis of a problem to a specific type or quality of data while ignoring those data

72 types that do not meet these restrictions is a documented form of interpretation bias termed

73 Macnamara's Fallacy (e.g. O’Mahony, 2017). Interpreting the tectonic history of rifted margins

74 using only a small part of the available well record risks introducing quantification bias. Our aim

75 here then is to develop an approach for using non-ideal well-data, along with those of higher

76 quality, to increase spatial resolution and to avoid falling for Macnamara's Fallacy.

77 An interpretation of the history of the Iberia-Newfoundland conjugate margin using a much

78 broader array of available real well data to minimise the effects of qualitative bias has not

79 previously been undertaken. Prior studies have examined the tectonic subsidence histories of

80 isolated basins within the proximal domain (e.g. Maldonado et al. 1999), forward modelled the

81 effects of tectonic subsidence on the margin from conjugate deep seismic profiles (Mohn et al.,

82 2015), looked at tectonic subsidence across the margin as a whole using idealised, stratigraphic

83 columns for the calculation of subsidence (Hiscott \& Wilson, 1990) or through the use of

84 synthetic "pseudo" wells (e.g. Alves and Cunha, 2018).

85 Key features of the Iberia-Newfoundland margin's development, such as the role of crustal

86 thinning or 'necking' (Keen \& Voogt, 1988; Lavier and Manatschal, 2006; Doré \& Lundin,

87 2015) remains contentious (as they do with other continental margins as well). Although much

88 work has been done on addressing issues such as this through forward modelling techniques, for

89 example, to estimate the nature of crustal thinning during pre-breakup rifting (e.g., Brune et al.,

90 2016), less attention has been given to the constraints of these models, especially regarding

91 variability along and across the margin conjugates. 
92 Furthermore, whilst passive continental margins are composed of a number of different domains,

93 including proximal, necking, distal and others (Peron-Pinvidic et al., 2013; Sutra et al., 2013),

94 which are known to deform in different styles at different times during the development of the 95 margin (Mohn et al., 2015), when rifting occurred across the margin as a whole is still a 96 contested point. In the case of the Iberia-Newfoundland conjugate margin, published work 97 suggests that rifting across all domains of the margin occurred in four distinct episodes (Alves et 98 al., 2002; Matias et al., 2011; Soares, 2014; Sousa Lemos Pereira, 2013). However, there is no 99 consensus on when these four periods occur, with different authors providing different 100 interpretations and active rifting periods that significantly overlap each other. Published 101 modelling studies (Biari et al., 2017; Brune et al., 2017; Manatschal et al., 2007) generally adopt 102 two active rifting phases: the first from Late Triassic to Early Jurassic, typified by slow rates of 103 thinning and depth independent, symmetrical rifting; and a second from Late Jurassic to Early 104 Cretaceous, where stretching speeds up dramatically with rifting becoming depth-dependent and 105 asymmetric. In regards to continental breakup, Pinheiro (1996) and Alves et al. (2006; 2009) 106 show breakup in the central North Atlantic margin occurs diachronously from south to north. 107 However, the timing of continental breakup is also contested, ranging from $\sim 132.9 \mathrm{Ma}$ (start 108 Hauterivian) to $\sim 113 \mathrm{Ma}$ (start Albian) (Bronner et al., 2011; Eddy, et al., 2017; Nirrengarten et 109 al., 2018; Vissers and Meijer, 2012).

110 In view of these kinds of discrepancies, we consider that additional ways of constraining the 111 style, timing and magnitude of subsidence within individual domains may lead to a better model 112 of overall margin development. The presence of hydrocarbon systems within the proximal 113 domain of both sides of the Iberia-Newfoundland margin has resulted in numerous exploration 114 wells being drilled. This provides the possibility of comparing the tectonic subsidence trends 
115 both spatially and temporally in the proximal domain. Accordingly, we pool sediment 116 accumulation records from 56 wells across the entire proximal domain of the Iberia117 Newfoundland conjugate margin to produce bulk averaged subsidence curves that describe the 118 nature of rifting within the domain as a whole and result in inferences that can be made regarding 119 the nature of rifting across all domains of the margin, i.e. breakup age, or rifting symmetry. This 120 allows a generalised interpretation of continental-breakup related subsidence patterns at the 121 Iberia-Newfoundland margin, derived from real wellbore data, for the first time. 2. METHOD

123 Input data for the present study were derived from publicly accessible sources (borehole data; 124 Canada-Newfoundland Board, 2017), from published literature on the Newfoundland (Driscoll \& 125 Hogg, 1995; Fensome et al., 2008) and Iberian margins (Alves et al., 2002, 2003 \& 2006; 126 Casacão, 2015; Kullberg, 2000; Lopez \& Proença Cunha, 2004; Maldonado et al., 1999; Matias 127 et al., 2011; Soares, 2014; Sousa Lemos Pereira, 2013). All wells available in the Iberian margin 128 literature were utilised (22); only a subset of the available wells from the Newfoundland side of 129 the margin were utilised (33) and were selected to give as even a data spread as possible across 130 the margin. Locations of all the wells used are shown on Fig. 1. $<$ Insert Fig. 1. here $>$

132 The use of wells drilled for hydrocarbon exploration presents the difficulty that they are often in 133 sub-optimal locations for calculation of tectonic subsidence, such as on high standing blocks or 134 next to salt diapers. Although every single chronostratigraphic unit was not present in every well, 135 a complete picture of the sedimentary deposition across a block was calculated by utilising the 136 averaging process as described in section 2.c to account for missing stratigraphy. Around 10 137 wells were used per block with at least one well per block penetrating to basement. This gave a 
138 good average of unit thicknesses across the varying structures present in the block. Figs. 2 and 3

139 show cross-sections of stratigraphy from each block grouped by geological period, detailed

140 stratigraphic columns of the lithologies encountered during these periods on either side of the 141 margin can be found in Alves and Cunha (2018). Two wells are highlighted for each block (3 for 142 Southern Iberia) that show different thicknesses of units from each geological period. No wells 143 were utilised in this work that were located above or adjacent to diapirs. $<$ Insert Fig. 2 and 3. here $>$

\section{2.a. Curve Generation}

146 The software used for modelling tectonic subsidence was Backstrip v4.3, a free to use 147 application for Mac OSX created by Nestor Cardozo (Cardozo, 2016). The program uses Airy 148 isostasy with exponential porosity reduction in either a water or air loaded setting to calculate 149 tectonic subsidence by backstripping input layers sequentially. Due to the depositional 150 environment of the continental margin the water loaded functionality was adopted. The program 151 supports backstripping of only one sedimentary column at a time so was run individually per 152 well with parameters specific to each.

153 Variable input parameters necessary to run the model include: top and base depths and ages, 154 grain densities, porosity coefficients and surface porosities for each of the units. Lithologies used 155 were either derived from stratigraphic columns of the individual wells or from a stratigraphic 156 column of the basin if only unit names were available from the well data. Parameters used for 157 each lithology can be found in Fig. 4(a)-4(c); the values used are not specific to the study area 158 but are standard values for the lithologies present (e.g. Allen \& Allen, 2013; Carmichael, 1982; 159 Hantschel \& Kauerauf, 2009; McWhorter \& Sunada, 1977). The same lithology parameters were 160 applied to units on either side of the margin. In the case of a unit that was composed of multiple 
161 lithologies, e.g. interbedded shales and sands, fractions of each lithology present were used and 162 summed together. Densities of $1000 \mathrm{~kg} / \mathrm{m}^{3}$ for water and $3300 \mathrm{~kg} / \mathrm{m}^{3}$ for the mantle were used 163 consistently for modelling subsidence at all locations. $<$ Insert Fig. 4. here $>$

165 Whilst data for the exact ages of each unit of an individual well were present for some Iberian 166 wells, most unit ages were derived from chronostratigraphic data from each basin being 167 compared to the International Commission on Stratigraphy chart (Cohen et al., 2013). If unit 168 ages are given as a geological stage from the chronostratigraphic chart it was assumed that the 169 unit basal age is the beginning of that stage and the unit top age is the end of the stage, unless:

170 (1) another unit is also present during the same time period; (2) the unit was either bound or split 171 by an unconformity; or (3) only part of a lithologically differentiated unit was present. In any of 172 these three cases, assumptions on age were made that would best represent the well data present. 173 Where data from an individual well contradicted that of the basin wide stratigraphic column an 174 interpretation was used that would respect the well data.

175 The backstripping method possesses the capability of taking sea level fluctuations into account 176 for calculations of tectonic subsidence although this was not used due to insufficient or 177 inaccurate data relating to depositional depths of many of the units across the margin. 178 Furthermore no attempt was made to correct for eroded strata, potentially indicated by 179 unconformities. Accordingly, the computed subsidence curves do not display any periods of 180 basement uplift. However, quantifying uplift or calculating exact numerical values of subsidence 181 was not within the main objectives of the work, which is focused on a comparison of subsidence 182 trends throughout the proximal domain of the conjugate margin.

\section{2.b. Errors}


184 There are two main sources of error present in computing the bulk averaged subsidence curves: 185 errors in the ages used for top and bottom of units and errors in the overall magnitude of 186 subsidence calculated using the modelling software. Using chronostratigraphic columns of each 187 basin, maximum and minimum possible ages for deposition of the top and base of each unit were 188 assigned and then their percentage deviations from the values used for computing the tectonic 189 subsidence curves were calculated. For maximum ages, the base age is assumed to be the oldest 190 possible from the chronostratigraphic column, with the top age assigned to an age halfway 191 through the overall length of unit deposition. For minimum ages, the base age is assigned to an 192 age halfway through the overall length of unit deposition, with the top age assumed to be the 193 youngest possible from the chronostratigraphic column. Percentage deviations of unit ages were 194 then collated and averaged for the Triassic, Jurassic and Cretaceous periods.

195 There are two sources of variability in how the backstripping software was used that affects the 196 magnitude of subsidence that it calculates for each well. The first is the value of the input 197 parameters used and the second is the combination of maximum or minimum values used for 198 each input parameter. Maximum and minimum values for the input parameters, derived from the 199 literature, are shown on Figs. 4(a)-4(c). Fig. 4(d) shows the results of all possible combinations 200 of maximum and minimum input parameters when running the modelling software. It is worth 201 noting that the combinations of these input parameters had a much larger effect on the calculated 202 magnitude of subsidence than the values of input parameters used. Therefore, the combinations 203 that were used to represent maximum and minimum subsidence conditions were selected to be 204 representative of real world conditions, as those that produced more extreme maximum and 205 minimum values were considered to be less likely to occur in nature. 


\section{2.c. Curve Averaging}

208 To allow the dataset of subsidence curves to be compared they have been grouped into 6 209 geographic blocks. These blocks, although arbitrary, were selected to be roughly the same size 210 whilst keeping wells from the same basin within the same block as much as possible. Wells on 211 the Newfoundland margin were selected to keep the number of wells in each block even. The 212 locations of the blocks and wells can be seen in Fig. 1.

213 Individual subsidence curves were then grouped with others from within the same block and a 214 mean subsidence curve was calculated to represent each block as shown in Figs. 5-10. Curves of 215 wells that did not penetrate the full depth of stratigraphy had the origin of their subsidence-axis 216 offset to the depth of mean subsidence in the block at the age of the oldest point in the well. This 217 was to account for the subsidence of the sediments below them that were undrilled and required 218 that at least one well per block penetrated to basement.

219 Subsidence at unconformities was set to a value of 0 for the duration of the hiatus, affecting the 220 overall averaging process. Thus, if all wells in a block present an unconformity at the same time, 221 so also would the average curve. However, in the case of an absence of observations (i.e. 222 redacted portion of publically available well data due to industry activity), the subsidence was set 223 to a null value and, hence, not included in the averaging for that margin segment in the period of 224 time it affects. For the dataset under consideration, this was encountered infrequently and its 225 consequence was negligible.

227 The mean curves for each block were then grouped (Fig. 11a) with their respective curves from 228 the opposite side of the margin and a mean subsidence curve was calculated to represent each of 229 the North, Centre or South segments of the margin so that trends laterally along the proximal 
230 domain of either margin could be compared (Fig. 11b). Curves from the same side of the margin 231 were also grouped together and a mean subsidence curve was calculated to represent either the 232 proximal domain of Iberia or Newfoundland so that overall trends could be compared (Fig. 11c). 233 The values of error envelopes were also grouped and averaged together in this way to give an 234 illustrative error estimates for the three blocks.

235 3. RESULTS AND DISCUSSION

236 3.a. Tectonic subsidence trends

237 Individual tectonic subsidence curves, generated per well, were compared with existing 238 databases of subsidence curves from the same area (e.g. Stapel et al., 1996) and found to be 239 comparable to one another, indicating that the input parameters used in the work, as well as the 240 curve generation, are sound.

241 The tectonic subsidence curve averaging methodology provides tectonic signatures for segments 242 of the continental margin that are of a scale appropriate for illuminating the large-scale tectonic 243 processes forming the continental margin as a whole, filtering out more local effects, for 244 example, related to basement structures and sediment transport systems. Thus, the conjugate 245 segment averaged curves seen in Fig. 11(b) each tend to define singular periods of syn-rift 246 subsidence (lasting continuously from the Late Triassic through to the Early Cretaceous) rather 247 than characterising a series of separate periods of active, syn-rift subsidence as suggested by the 248 more detailed studies mentioned in the Introduction.

249 All three segments under consideration (North, Centre and South) display this amalgamated 250 "syn-rift" period of continuous subsidence at a high rate, in each case accommodating the bulk of 251 tectonic subsidence that occurs prior to breakup. However, there are differences observed in the 252 timing at which this period occurs: in the Centre segment it occurs from $\sim 227 \mathrm{Ma}$ (start Norian) 
253 to $\sim 152.1 \mathrm{Ma}$ (start Tithonian); in the South segment it occurs from $\sim 208.5 \mathrm{Ma}$ (start Rhaetian) to $254 \sim 152.1 \mathrm{Ma}$ (start Tithonian); and in the North segment it occurs from $\sim 201.3 \mathrm{Ma}$ (start 255 Hettangian) to $\sim 132.9 \mathrm{Ma}$ (start Hauterivian). The onset age is based on the observed break over 256 to high tectonic subsidence rates such as typically associated with active, syn-rift extension (e.g. 257 Allen and Allen, 2013) and the termination age is based on the transition to tectonic subsidence 258 rates that have more the appearance of exponentially decaying (concave upwards), more typical 259 of post-rift, passive subsidence. The choice of the termination dates is somewhat arbitrary, being 260 only qualitatively determined, and keeping in mind that this apparent transition marks only the 261 cessation of rifting in the proximal domain with break-up of the continental margin and, hence, 262 the end of active rifting, occurring after.

263 The quantified age error estimates for each segment subsidence curve do not overlap suggesting 264 that the contrast in rift onset timing is robust when considering segments as a whole. Moreover, 265 the observed Centre to South to North migration of rifting in the proximal domain can be seen in 266 the subsidence curves from each block on either side of the margin in Fig. 11(a), also indicating 267 that the trends are not an artifact of the averaging process.

268 Although the mean curve of each segment displays a pseudo "syn-rift" phase, the overall trend of 269 these curves differs, indicating fundamental differences in the nature of rifting in the segment 270 (Xie and Heller, 2006). From Fig. 11(b) it can be seen that the rates of subsidence, during the 271 amalgamated "syn-rift" period vary between segments. In the Centre it occurs at a rate of $\sim 17$ $272 \mathrm{~m} / \mathrm{Ma}$, in the South it occurs at a rate of $\sim 14 \mathrm{~m} / \mathrm{Ma}$ and in the North it occurs at a rate of $\sim 17$ $273 \mathrm{~m} / \mathrm{Ma}$. The Centre segment curve exhibits its greatest rate of subsidence almost immediately 274 after "syn-rift" subsidence begins, giving a trend of almost continuous rapid subsidence that 275 lacks any significant punctuation. The North and South segments instead both display a period of 
276 low rate tectonic subsidence that precedes the initiation of the amalgamated "syn-rift" phase, and 277 thereafter display a much more stepped trend indicating a more irregular rifting history with 278 multiple observable episodes. This is due to only one well being present in the Northern 279 Newfoundland block penetrating deeper than 170Ma. If the assumption is made that a higher 280 than average amount of subsidence occurred in the well at this time, then the South and North 281 segment mean curves would display almost an identical subsidence rate and trend.

282 Fig. 11(c) shows all three blocks from either side of the margin averaged together to look at cross 283 margin trends. It can be seen that - overall, despite the diachroneity revealed by considering 284 individual segments - one side of the margin does not rift prior to the other. There are three 285 periods of similarity, both in rate and magnitude of subsidence, across the margin: (1) $\sim 227 \mathrm{Ma}$ 286 (start Norian) to $\sim 199.3 \mathrm{Ma}$ (start Sinemurian); (2) $\sim 182.7 \mathrm{Ma}$ (start Toarcian) to $\sim 170.3 \mathrm{Ma}$ (start 287 Bajocian); (3) $\sim 152.1 \mathrm{Ma}$ (start Tithonian) to $\sim 113 \mathrm{Ma}$ (start Albian). It is only outside of these 288 three periods when the subsidence curves of the conjugate margins can be seen to diverge from 289 each other, with more rapid tectonic subsidence occurring in the Newfoundland conjugate 290 compared to the Iberian one $\sim 199.3 \mathrm{Ma}$ (start Sinemurian) to $\sim 182.7 \mathrm{Ma}$ (start Toarcian) and $291 \sim 170.3 \mathrm{Ma}$ (start Bajocian) to $\sim 152.1 \mathrm{Ma}$ (start Tithonian).

292 It is of course well-known that basins on the Newfoundland side of the margin are much thicker, 293 with greater accommodation space provided by tectonically-driven subsidence, than on the 294 Iberian side and that this is intrinsically linked to the asymmetric nature of this particular 295 conjugate margin of the Atlantic Ocean (Manatschal et al., 2007). However, the bulk averaged 296 tectonic subsidence curves computed here demonstrate that there are two possibly distinct 297 periods during which asymmetrical stretching occurred in the proximal domain, both of them 298 during the Jurassic, at least at a whole basin, regional, scale. 
299 The potential impact of sediment supply on attributing to these trends was interrogated and found 300 to be unlikely. During the period of high subsidence (Jurassic) where trends in the subsidence

301 curves laterally and across the margin have been observed, formations are found to be very 302 similar between blocks on the same side of the margin with the dominant depositional 303 environment being marine, suggesting that trends laterally along the margin are tectonic in 304 origin. During this period lithologies deposited in Iberia include marine carbonates with some 305 shaley interbeds (Alves et al., 2002, 2003 \& 2006; Casacão, 2015; Kullberg, 2000; Lopez \& 306 Proença Cunha, 2004; Maldonado et al., 1999; Matias et al., 2011; Soares, 2014; Sousa Lemos 307 Pereira, 2013), and in Newfoundland, open marine successions of shales and sands with some 308 carbonate interbeds (Canada-Newfoundland Board, 2017; Driscoll \& Hogg, 1995; Fensome et 309 al., 2008). Deltaic sequences, which are the most likely to indicate a sedimentary supply 310 influence on subsidence curves, are not present on either side of the margin from Earliest 311 Jurassic through post Aptian. Due to the slightly different depositional environments between the 312 Iberian and Newfoundland sides of the margin during the Jurassic, a sedimentary supply effect 313 on the disparity between overall magnitude of subsidence on either side of the margin at breakup 314 cannot be entirely ruled out. However the depositional environments are similar enough that 315 rates of deposition would be comparable, indicating a different cause for this disparity.

\section{3.b. Possible implications}

317 The objectives of the present study were to compute bulk averaged tectonic subsidence curves 318 for appropriate conjugate blocks in the proximal domain of the Iberia-Newfoundland conjugate 319 continental margin and to describe how these results may usefully contribute to increased 320 understanding of the nature of stretching across margin as a whole and how the results may 321 provide necessary constraints for future modelling studies. A thorough investigation of these 
322 results in terms of a new interpretation of the tectonic evolution of the entire Iberia-

323 Newfoundland margin are not intended. Nevertheless, they offer additional insights into the 324 development of the margin.

325 Numerous papers describe a migration of continental breakup from South to North along the 326 Iberia-Newfoundland margin (e.g. Mohn et al., 2015; Brune et al., 2016) and although timing of 327 breakup cannot be derived from this work, rifting leading to breakup can be seen to cease in the 328 proximal domain, therefor inferred to migrate to distal and hyperextended domains, $\sim 152.1 \mathrm{Ma}$ 329 (start Tithonian) in the South and Centre and $\sim 132.9 \mathrm{Ma}$ (start Hauterivian) in the North. These 330 results are fitting with the observed South to North rift propagation in the hyperextended domain 331 that lead to breakup. It notable that stretching in the proximal domain instead propagates Centre 332 to South to North, a trend that does not mirror that of eventual breakup.

333 Another feature that has been noted in previous work is the depth independent symmetrical 334 nature of initial rifting (Mohn et al., 2015; Brune et al., 2016), by which it is meant evenly 335 distributed strain of similar timing and magnitude on both margin conjugates. Here, it was found 336 that conjugate block average curves do appear symmetrical during the first period of rifting (Fig. 337 11c), suggesting that there is no large scale cross-margin propagation of rifting occurring in the 338 early stages of margin formation, via a crustal scale, "simple" shear/fault zone (e.g. Lister et al., 339 1991; Wernicke, 1985). However, rifting in the stretching phase of the proximal domain was 340 found to be generally symmetrical but with notable exceptions of contrasting subsidence rates on 341 either side of the margin during two isolated periods of tectonic subsidence in the Jurassic. This 342 suggests the possibility that whatever process causes asymmetry on this conjugate margin as a 343 whole began during the rifting stage. 
344 Manatschal et al. (2007) suggested that inherent crustal heterogeneities are an important

345 constraint on how rifting manifests itself and propagates. One important source of heterogeneity

346 in the study area is pre-rift magmatic underplating below Iberia. Although emplaced during the

347 Permian, prior to the onset of rifting leading to continental breakup in this area, Mohn et al.

348 (2015) argued that the cooling of this underplate resulted in the development of the first

349 sedimentary depocentres during the Triassic. This could provide an explanation to the trends

350 seen in the bulk averaged tectonic subsidence curves, with the North and South segments

351 displaying a period of low rate subsidence during the Triassic prior to the initiation of active

352 rifting. As this period is not evident in the curve of the Centre segment and the rate and trend

353 overall differs from the North and South segments this may imply a lesser degree or absence of

354 underplating beneath the Centre segment. Further, as the effects of sediment supply on observed

355 trends has been interrogated and found unlikely to be a factor, it's possible that pre-rift

356 underplating may also offer an explanation as to the timing of rifting initiating in each segment

357 of the margin and may also be a factor contributing to the magnitude of subsidence in

358 Newfoundland being $\sim 50 \%$ higher than in Iberia at breakup.

359 3.c. Methodological limitations

360 That potentially important implications for the evolution of the Newfoundland-Iberia conjugate

361 margin that have been identified demonstrates the strength of processing a large dataset of

362 subsidence curves in the way described in this work, allowing a 3D view of basin subsidence

363 trends across the margin in a very simple manner. Previous work has modelled in 2D along deep

364 seismic lines, which limited the insight gained laterally along the margin, or has utilised idealised

365 stratigraphic columns from basins across the margin. Whilst the use of generalised stratigraphy

366 addresses the issue of 3D data spread it adds another stage of interpretation increasing the risk 
367 that assumptions are made that may not be applicable to all areas of the basin. By using real 368 world stratigraphic columns encountered in wellbores and backstripping the results, therefore 369 removing as much interpretation bias as possible, a clearer insight into the nature of rifting along 370 the Newfoundland-Iberia margin has been gained.

371 It is important to note, however, that the mean curves produced in this work do not represent 372 subsidence at any real-world location. They have been created in a way to show average 373 subsidence of designated blocks so that relative trends along and across the margin as a whole 374 can be identified, and as such do not represent any tangible real world location.

\section{4. CONCLUSION}

376 By creating average subsidence curves for the Iberia-Newfoundland margins of the northern 377 Central Atlantic Ocean from a large dataset of wells from the conjugate proximal margins 378 themselves, the results of this work provide additional insights into the conjugate margin's 379 development. The findings suggest that the main rifting phase and associated tectonic subsidence 380 began earlier in the central part of the proximal margin ( $227 \mathrm{Ma}$, start Norian) than in its 381 southern segment, ( 208.5Ma, start Rhaetian) and in its northern segment ( 201.3Ma, start 382 Hettangian).

383 The rifting trend identified in this work, contrast with the overall south to north trend of breakup 384 along the Atlantic that has been recorded in previous studies, showing that rifting in the proximal 385 domain prior to continental breakup does not necessarily mirror the trend of rifting in the 386 hyperextended domain. The timing of initial subsidence as it is expressed in each block of the 387 studied margin segment could be linked to the differential distribution of pre-rift, magmatic 388 underplating below Iberia. Other observations, such as the Newfoundland side of the margin 389 subsiding 50\% more than the Iberian side prior to continental breakup, which occurs during two 
390 isolated periods in the Jurassic, could also be explained by the presence of magmatic 391 underplating below Iberia.

392 The results of this analysis of the Iberia-Newfoundland margin demonstrates the usefulness of 393 using our proposed workflow for identifying subsidence trends in large datasets of wellbore data 394 along conjugate margins and supplements rather than only complements results based on deep 395 seismic lines that other studies have relied upon. The potential for introducing bias to studies by 396 focusing just on a limited number of wells was recognised from the earliest attempts to backstrip 397 stratigraphic records in basins. The approach applied here to the Iberia-Newfoundland margin 398 offers opportunities for limiting these biases. Simply ignoring wells that do not have the full data 399 record necessary for accurate backstopping is an example of Macnamara's Fallacy - risking the 400 introduction of significant quantification bias in a study. However, wells still need screening to 401 avoid incorporating those sites where the stratigraphic record has responded to non-tectonic 402 motions such as caused by salt mobility. Together the results obtained in this work may be used 403 to provide insights into the geodynamic scale processes driving lithosphere rifting prior to 404 continental breakup and more relevant constraints for future forward modelling studies on the 405 Iberia-Newfoundland margin and on conjugate margins in general.

407 REFERENCES CITED

408 Allen, P. \& Allen, J. (2013). Basin Analysis: Principles and Application to Petroleum Play 409 Assessment. 3rd ed. New Jersey: Wiley-Blackwell.

410 Alves, T., Gawthorpe, R., Hunt, D. and Monteiro, J. (2002). Jurassic tectono-sedimentary 411 evolution of the Northern Lusitanian Basin (offshore Portugal). Marine and Petroleum $412 \quad$ Geology, 19(6), pp.727-754. 
413 Alves, T., Gawthorpe, R., Hunt, D. and Monteiro, J. (2003). Post-Jurassic tectono-sedimentary 414 evolution of the Northern Lusitanian Basin (Western Iberian margin). Basin Research, 15(2), $415 \quad$ pp. 227

416 Alves, T., Moita, C., Sandnes, F., Cunha, T,. Monteiro, J. \& Pinheiro, L. (2006). Mesozoic417 Cenozoic evolution of North Atlantic continental-slope basins: The Peniche basin, western 418 Iberian margin. AAPG Bulletin, 90 (1).-249.

419 Alves, T., Moita, C., Cunha, T., Ullnaess, M., Myklebust, R., Monteiro, J. and Manuppella, G. 420 (2009). Diachronous evolution of Late Jurassic-Cretaceous continental rifting in the 421 northeast Atlantic (west Iberian margin). Tectonics, 28(4).

422 Alves, T. and Abreu Cunha, T. (2018). A phase of transient subsidence, sediment bypass and 423 deposition of regressive-transgressive cycles during the breakup of Iberia and 424 Newfoundland. Earth and Planetary Science Letters, 484, pp.168-183.

425 Barton, P. and Wood, R., (1984). Tectonic evolution of the North Sea Basin: crustal stretching $426 \quad$ and subsidence. Geophys. J.R. Astron. Soc., 79: 987-1022.

427 Biari, Y., Klingelhoefer, F., Sahabi, M., Funck, T., Benabdellouahed, M., Schnabel, M., 428 Reichert, C., Gutscher, M., Bronner, A. and Austin, J. (2017). Opening of the central 429 Atlantic Ocean: Implications for geometric rifting and asymmetric initial seafloor spreading $430 \quad$ after continental breakup. Tectonics, 36(6), pp.1129-1150.

431 Bronner, A., Sauter, D., Manatschal, G., Péron-Pinvidic, G. and Munschy, M. (2011). Magmatic 432 breakup as an explanation for magnetic anomalies at magma-poor rifted margins. Nature 433 Geoscience, 4(8), pp.549-553. 
434 Brune, S., Heine, C., Clift, P. and Pérez-Gussinyé, M. (2017). Rifted margin architecture and 435 crustal rheology: Reviewing Iberia-Newfoundland, Central South Atlantic, and South China 436 Sea. Marine and Petroleum Geology, 79, pp.257-281.

437 Brune, S., Williams, S., Butterworth, N. and Müller, R. (2016). Abrupt plate accelerations shape 438 rifted continental margins. Nature, 536(7615), pp.201-204.

439 Canada-Newfoundland Offshore Petroleum Board. (2017). Schedule of Wells \|| CNLOPB. 440 [online] Cnlopb.ca. Available at: http://www.cnlopb.ca/wells/ [Accessed 21 Mar. 2017 ].

441 Cardozo, N. (2016). Backstrip v4.3. Stavanger: Nestor Cardozo.

442 Carmichael, R. (1982). CRC handbook of physical properties of rocks. Boca Raton, Fla.: CRC 443 Press.

444 Casacão, J. (2015). Tectono-Estratigrafia e Modelação de Sistemas Petrolíferos da Bacia do 445 Porto. PhD Thesis, Universidade de Lisboa.

446 Cohen, K.M., Finney, S.M., Gibbard, P.L., Fan, J.-X., (2013). The ICS International 447 Chronostratigraphic Chart. Episodes 36, 199-204.

448 DeSilva, N.R., 1999, Sedimentary basins and petroleum systems offshore Newfoundland and 449 Labrador, in A.J. Fleet, and S.A.R. Boldy (eds.), Petroleum Geology of Northwest Europe: 450 Proceedings of the 5th Conference: The Geological Society, London, p. 501-515.

451 Doré, T. and Lundin, E. (2015). Hyperextended continental margins-Knowns and unknowns. 452 Geology, 43(1), pp.95-96.

453 Driscoll, N. and Hogg, J. (1995). Stratigraphic response to basin formation: Jeanne d'Arc Basin, 454 offshore Newfoundland. Geological Society, London, Special Publications, 80(1), pp.145455163. 
456 Eddy, M., Jagoutz, O. and Ibañez-Mejia, M. (2017). Timing of initial seafloor spreading in the 457 Newfoundland-Iberia rift. Geology, 45(6), pp.527-530.

458 Enachescu, M. and Fagan, P. (2005). Call for bids, no. NL05-1, [parcels 1, 2 and 3 regional 459 setting and petroleum geology evaluation. St. John's, Nfld.: Canada-Newfoundland Offshore $460 \quad$ Petroleum Board.

461 Fagan, A. (2010). Structural and stratigraphic study of the Laurentian basin, offshore Eastern 462

463 Fensome, R., Crux, J., Gard, G., MacRae, A., Williams, G., Thomas, F., Fiorini, F. and Wach, G. 464 (2008). The last 100 million years on the Scotian Margin, offshore eastern Canada: an event465 stratigraphic scheme emphasizing biostratigraphic data. Atlantic Geology, 44(1), p.93.

466 Hansen, M., Scheck-Wenderoth, M., Hübscher, C., Lykke-Andersen, H., Dehghani, A., Hell, B. 467 and Gajewski, D. (2007). Basin evolution of the northern part of the Northeast German 468 Basin - Insights from a 3D structural model. Tectonophysics, 437(1-4), pp.1-16.

469 Hantschel, T. and Kauerauf, A. (2009). Fundamentals of basin and petroleum systems modeling. $470 \quad 1$ st ed. Dordrecht: Springer.

471 Hiscott, R. \& Wilson, R. (1990). Comparative Stratigraphy and Subsidence History of Mesozoic 472 Rift Basins of North Atlantic (1). AAPG Bulletin, 74.

473 Hopper, J., Funck, T., Tucholke, B., Louden, K., Holbrook, W. and Christian Larsen, H. (2006). 474 A deep seismic investigation of the Flemish Cap margin: implications for the origin of deep 475 reflectivity and evidence for asymmetric break-up between Newfoundland and Iberia. 476 Geophysical Journal International, 164(3), pp.501-515.

477 Keen, C. and de Voogd, B. (1988). The continent-ocean boundary at the rifted margin off eastern 478 Canada: New results from deep seismic reflection studies. Tectonics, 7(1), pp.107-124. 
479 Kullberg, J. (2000). Evolucao tectonica Mesozoica da Bacia Lusitaniana. PhD Thesis, $480 \quad$ Universidade de Lisboa.

481 Lavier, L. and Manatschal, G. (2006). A mechanism to thin the continental lithosphere at 482 magma-poor margins. Nature, 440, pp.324-328.

483 Lister, G., Etheridge, M. and Symonds, P. (1991). Detachment models for the formation of 484 passive continental margins. Tectonics, 10(5), pp.1038-1064.

485 Lopez, F. \& Proença Cunha, P. (2004). Tertiary tectono-sedimentary characterisation of the 486 Algarve margin (SW Iberia). Boletín Geológico y Minero, 115(3): 511-520.

487 Maldonado, A., Somoza, L. and Pallarés, L. (1999). The Betic orogen and the Iberian-African 488 boundary in the Gulf of Cadiz: geological evolution (central North Atlantic). Marine 489 Geology, 155(1-2), pp.9-43.

490 Manatschal, G., Müntener, O., Lavier, L., Minshull, T. and Péron-Pinvidic, G. (2007). 491 Observations from the Alpine Tethys and Iberia-Newfoundland margins pertinent to the 492 interpretation of continental breakup. Geological Society, London, Special Publications, $493 \quad 282(1)$, pp.291-324.

494 Matias, H., Kress, P., Terrinha, P., Mohriak, W., Menezes, P., Matias, L., Santos, F. and 495 Sandnes, F. (2011). Salt tectonics in the western Gulf of Cadiz, southwest Iberia. AAPG $496 \quad$ Bulletin, 95(10), pp.1667-1698.

497 McWhorter, D. and Sunada, D. (1977). Ground-water hydrology and hydraulics. 1st ed. Water $498 \quad$ Resources Publication.

499 Mohn, G., Karner, G., Manatschal, G. and Johnson, C. (2015). Structural and stratigraphic 500 evolution of the Iberia-Newfoundland hyper-extended rifted margin: a quantitative 501 modelling approach. Geological Society, London, Special Publications, 413(1), pp.53-89. 
502 Nirrengarten, M., Manatschal, G., Tugend, J., Kusznir, N. and Sauter, D. (2018). Kinematic 503 Evolution of the Southern North Atlantic: Implications for the Formation of Hyperextended $504 \quad$ Rift Systems. Tectonics, 37(1), pp.89-118.

505 O'Mahony, S. (2017). Medicine and the McNamara fallacy. Journal of the Royal College of $506 \quad$ Physicians of Edinburgh, 47(3), pp.281-287.

507 Peron-Pinvidic, G., Manatschal, G. and Osmundsen, P. (2013). Structural comparison of 508 archetypal Atlantic rifted margins: A review of observations and concepts. Marine and $509 \quad$ Petroleum Geology, 43, pp.21-47.

510 Pimentel, N. and Pena dos Reis, R. (2016). Petroleum systems of the West Iberian margin: A 511 review of the Lusitanian basin and the deep offshore Peniche basin. Journal of Petroleum 512 Geology, 39(3), pp.305-326.

513 Pinheiro, L \& Wilson, RCL \& Reis, Rui \& Whitmarsh, RB \& Ribeiro, A. (1996). The western 514 Iberia Margin: a geophysical and geological overview. Proceedings of the ocean drilling 515 program. Scientific Results. 149. 3-23.

516 Rasmussen, E., Lomholt, S., Andersen, C. and Vejbæk, O. (1998). Aspects of the structural 517 evolution of the Lusitanian Basin in Portugal and the shelf and slope area offshore Portugal. $518 \quad$ Tectonophysics, 300(1-4), pp.199-225.

519 Sibuet, J. and Tucholke, B. (2012). The geodynamic province of transitional lithosphere adjacent 520 to magma-poor continental margins. Geological Society, London, Special Publications, $521 \quad 369(1)$, pp.429-452.

522 Soares, D. (2014). Sedimentological and stratigraphical aspects of the syn- to post-rift transition 523 on fully separated conjugate margins. PhD Thesis, Cardiff University. 
524 Sousa Lemos Pereira, R. (2013). Continental rifting and postbreakup evolution of Southwest 525 Iberia: Tectono $\square$ stratigraphic record of the first segment of the North Atlantic Ocean. PhD 526 Thesis, Cardiff University.

527 Srivastava, S., Sibuet, J., Cande, S., Roest, W. and Reid, I. (2000). Magnetic evidence for slow 528 seafloor spreading during the formation of the Newfoundland and Iberian margins. Earth 529 and Planetary Science Letters, 182(1), pp.61-76.

530 Stapel, G., Cloetingh, S. and Pronk, B. (1996). Quantitative subsidence analysis of the Mesozoic 531 evolution of the Lusitanian basin (western Iberian margin). Tectonophysics, 266(1-4), $532 \quad$ pp.493-507.

533 Steckler, M. and Watts, A. (1978). Subsidence of the Atlantic-type continental margin off New $534 \quad$ York. Earth and Planetary Science Letters, 41(1), pp.1-13.

535 Steckler, M., Mountain, G., Miller, K. and Christie-Blick, N. (1999). Reconstruction of Tertiary 536 progradation and clinoform development on the New Jersey passive margin by 2-D 537 backstripping. Marine Geology, 154(1-4), pp.399-420.

538 Sutra, E., Manatschal, G., Mohn, G. and Unternehr, P. (2013). Quantification and restoration of 539 extensional deformation along the Western Iberia and Newfoundland rifted margins. $540 \quad$ Geochemistry, Geophysics, Geosystems, 14(8), pp.2575-2597.

541 Vissers, R. and Meijer, P. (2012). Mesozoic rotation of Iberia: Subduction in the Pyrenees?.

542 Earth-Science Reviews, 110(1-4), pp.93-110.

543 Wernicke, B. (1985). Uniform-sense normal simple shear of the continental lithosphere. 544 Canadian Journal of Earth Sciences, 22(1), pp.108-125.

545 Xie, X. and Heller, P. (2006). Plate tectonics and basin subsidence history. Geological Society of $546 \quad$ America Bulletin, preprint(2008), p.1. 


\section{FIGURE CAPTIONS}

549 Figure 1. (Colour online) Plate reconstruction of Iberia-Newfoundland at chron M0 (125Ma, start

Aptian) from Sibuet and Tucholke (2012) and Srivasta et al. (2000). Locations of all wells used in the study are shown as black dots. The green lines display the arbitrary blocks used in this work for curve averaging. The grey box indicates the Newfoundland-Gibraltar Fracture Zone.

554 Figure 2. (Colour online) Map of present day Newfoundland with present day depocentres displayed and labelled and with all wells used in the study shown, wells penetrating to basement in red. The green lines display the blocks used in this work for curve averaging. Section a-a' is adapted from DeSilva (1999). Section b-b' is adapted from Fagan (2010). Key of units in cross sections can be found in Fig. 3. Well Carey J-34 is offset from the cross section but sits in an equivalent structural location.

Figure 3. (Colour online) Map of present day Iberia with present day depocentres displayed and labelled and with all wells used in the study shown, wells penetrating to basement in red. The green lines display the arbitrary blocks used in this work for curve averaging. Section c-c' is adapted from Alves et al (2006). Section d-d' is adapted from Pimentel and Pena dos Reis (2016). Section e-e' is adapted Rasmussen et al (1998).

Figure 4. (Colour online) Input parameters of each lithology used (the lithology labelled salt, represents all evaporites) in the model along with maximum and minimum values that have been used to calculate the error of the model: (a) Porosity Coefficient (C); (b) Surface Porosity $(\Phi)$; (c) Grain density $(\rho)$. (d) Output variations of running the model 569 under all possible input parameter configurations and the configurations used. 1=Min 
$\rho, \operatorname{Min} C$ and $\operatorname{Max} \Phi ; 2=\operatorname{Min} \rho, \operatorname{Max} C$ and $\operatorname{Max} \Phi ; 3=\operatorname{Min} \rho, \operatorname{Min} C$ and $\operatorname{Min} \Phi ; 4=$ $\operatorname{Min} \rho, \operatorname{Max} C$ and $\operatorname{Min} \Phi ; 5=\operatorname{Max} \rho, \operatorname{Min} C$ and $\operatorname{Max} \Phi ; 6=\operatorname{Max} \rho, \operatorname{Max} C$ and Max $\Phi, 7=\operatorname{Max} \rho, \operatorname{Min} C$ and $\operatorname{Min} \Phi ; 8=\operatorname{Max} \rho, \operatorname{Max} C$ and $\operatorname{Min} \Phi$.

573 Figure 5. (Colour online) (a) Tectonic subsidence (water loaded) of individual wells of the North 574 Newfoundland block and their numerical mean. (b) Maximum and minimum errors for both subsidence and age on the North Newfoundland block mean curve.

576 Figure 6. (Colour online) (a) Tectonic subsidence (water loaded) of individual wells of the North 577 Iberia block and their numerical mean. (b) Maximum and minimum errors for both subsidence and age on the North Iberian block mean curve.

579 Figure 7. (Colour online) (a) Tectonic subsidence (water loaded) of individual wells of the 580 Centre Newfoundland block and their numerical mean. (b) Maximum and minimum errors for both subsidence and age on the Centre Newfoundland block mean curve.

582 Figure 8. (Colour online) (a) Tectonic subsidence (water loaded) of individual wells of the 583 584

585 Figure 9. (Colour online) (a) Tectonic subsidence (water loaded) of individual wells of the South 586 Centre Iberia block and their numerical mean. (b) Maximum and minimum errors for both subsidence and age on the Centre Iberian block mean curve.

588 Figure 10. (Colour online) (a) Tectonic subsidence (water loaded) of individual wells of the South Iberia block and their numerical mean. (b) Maximum and minimum errors for both subsidence and age on the South Iberian block mean curve.

591 Figure 11. (Colour online) (a) Mean tectonic subsidence curves (water loaded) for each block on 592 either side of the margin. (b) Mean tectonic subsidence curve (water loaded) for each 
593 segment of the margin and their associated error as an envelope. (c) Mean tectonic 594 subsidence curve (water loaded) for each side of the margin as a whole and their 595 associated error as an envelope. 


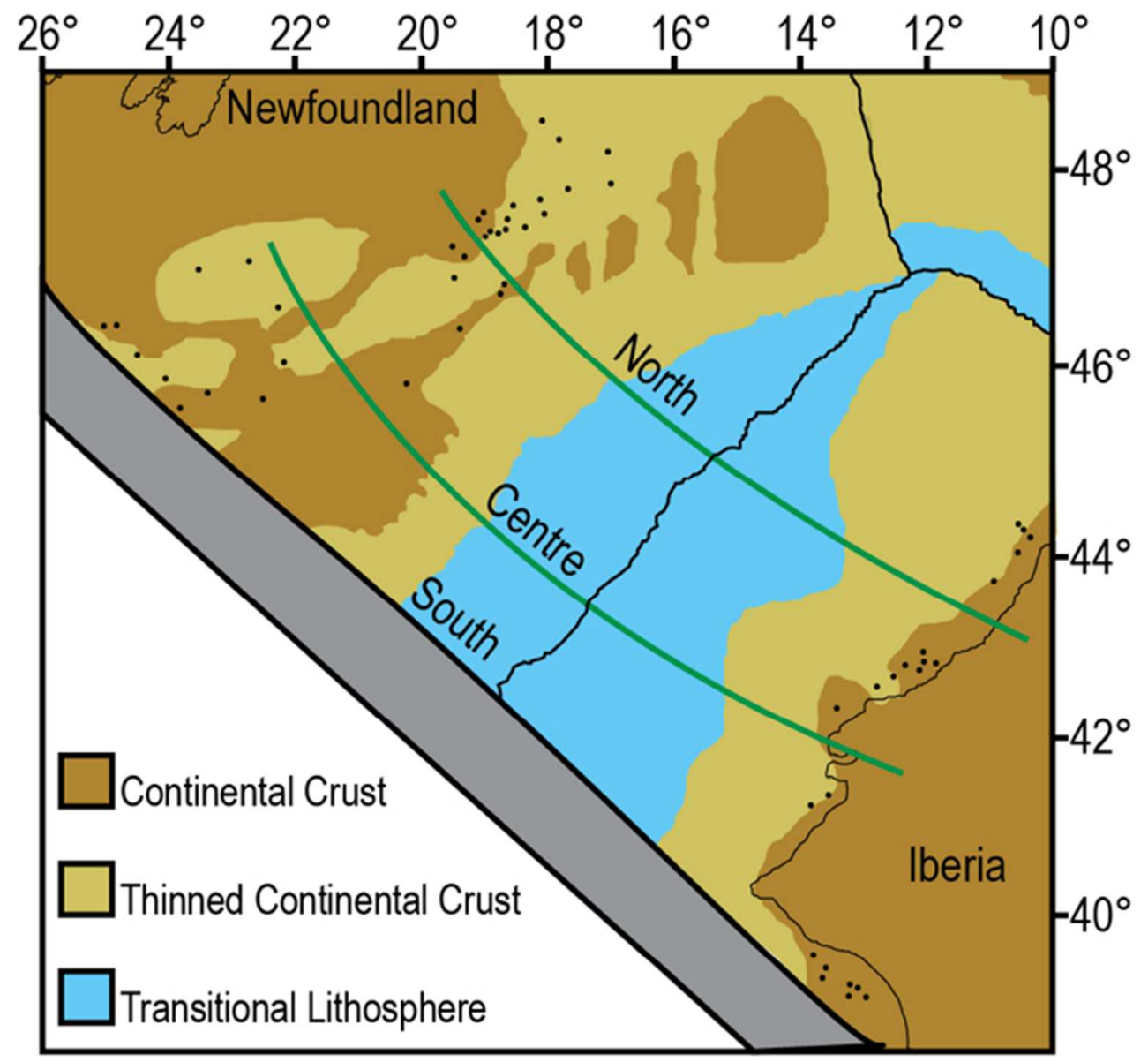

Plate reconstruction of Iberia-Newfoundland at chron M0 (125Ma, start Aptian) from Sibuet and Tucholke (2012) and Srivasta et al. (2000). Locations of all wells used in the study are shown as black dots. The green lines display the arbitrary blocks used in this work for curve averaging. The grey box indicates the Newfoundland-Gibraltar Fracture Zone. 
Map of present day Newfoundland with present day depocentres displayed and labelled and with all wells used in the study shown, wells penetrating to basement in red. The green lines display the blocks used in this work for curve averaging. Section $a-a^{\prime}$ is adapted from DeSilva (1999). Section b-b' is adapted from Fagan (2010). Key of units in cross sections can be found in Fig. 3. Well Carey J-34 is offset from the cross section but sits in an equivalent structural location.

$117 \times 141 \mathrm{~mm}(150 \times 150 \mathrm{DPI})$ 


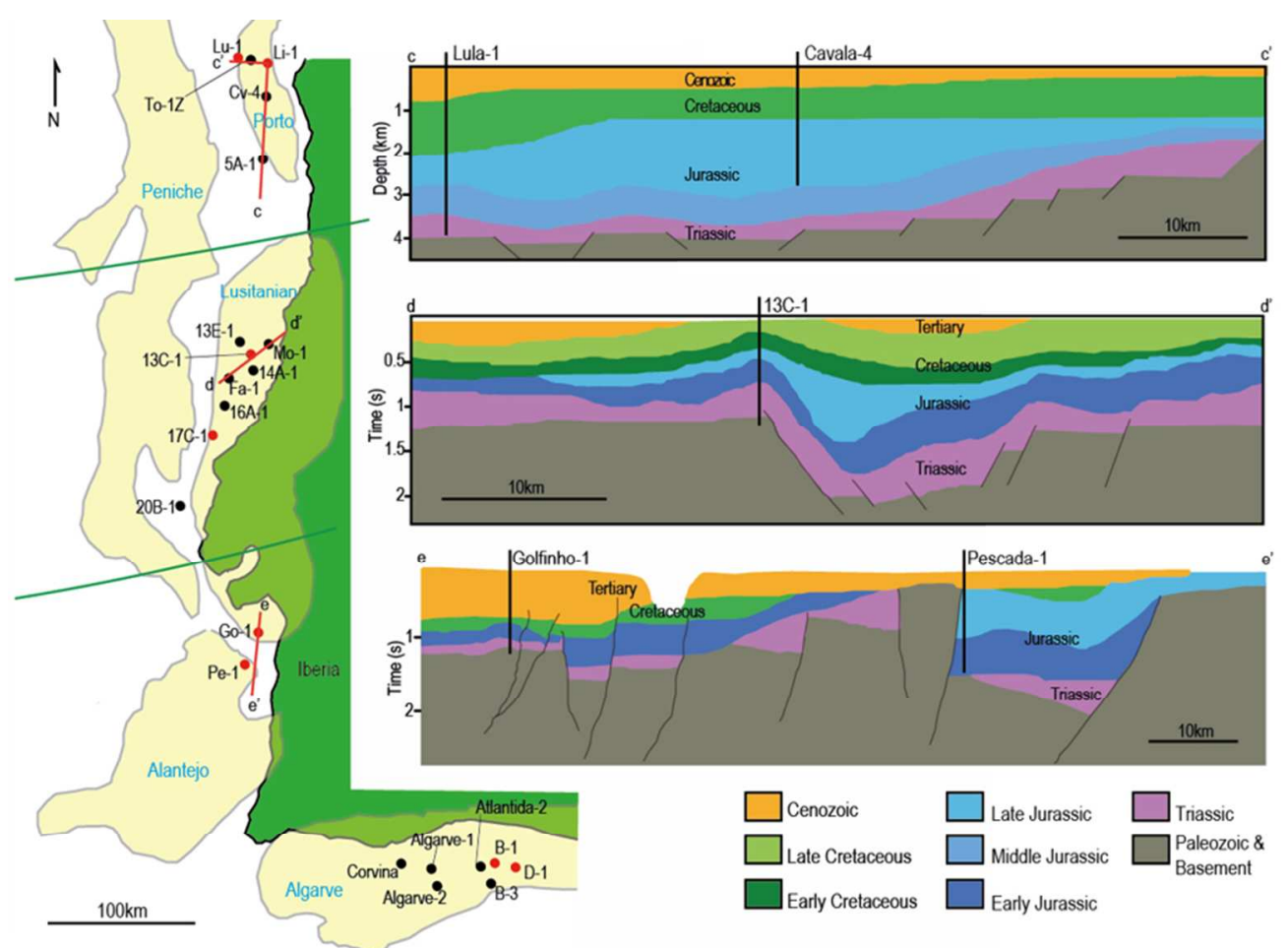

Map of present day Iberia with present day depocentres displayed and labelled and with all wells used in the study shown, wells penetrating to basement in red. The green lines display the arbitrary blocks used in this work for curve averaging. Section $c-c^{\prime}$ is adapted from Alves et al (2006). Section d- $d^{\prime}$ is adapted from Pimentel and Pena dos Reis (2016). Section e-e' is adapted Rasmussen et al (1998). 


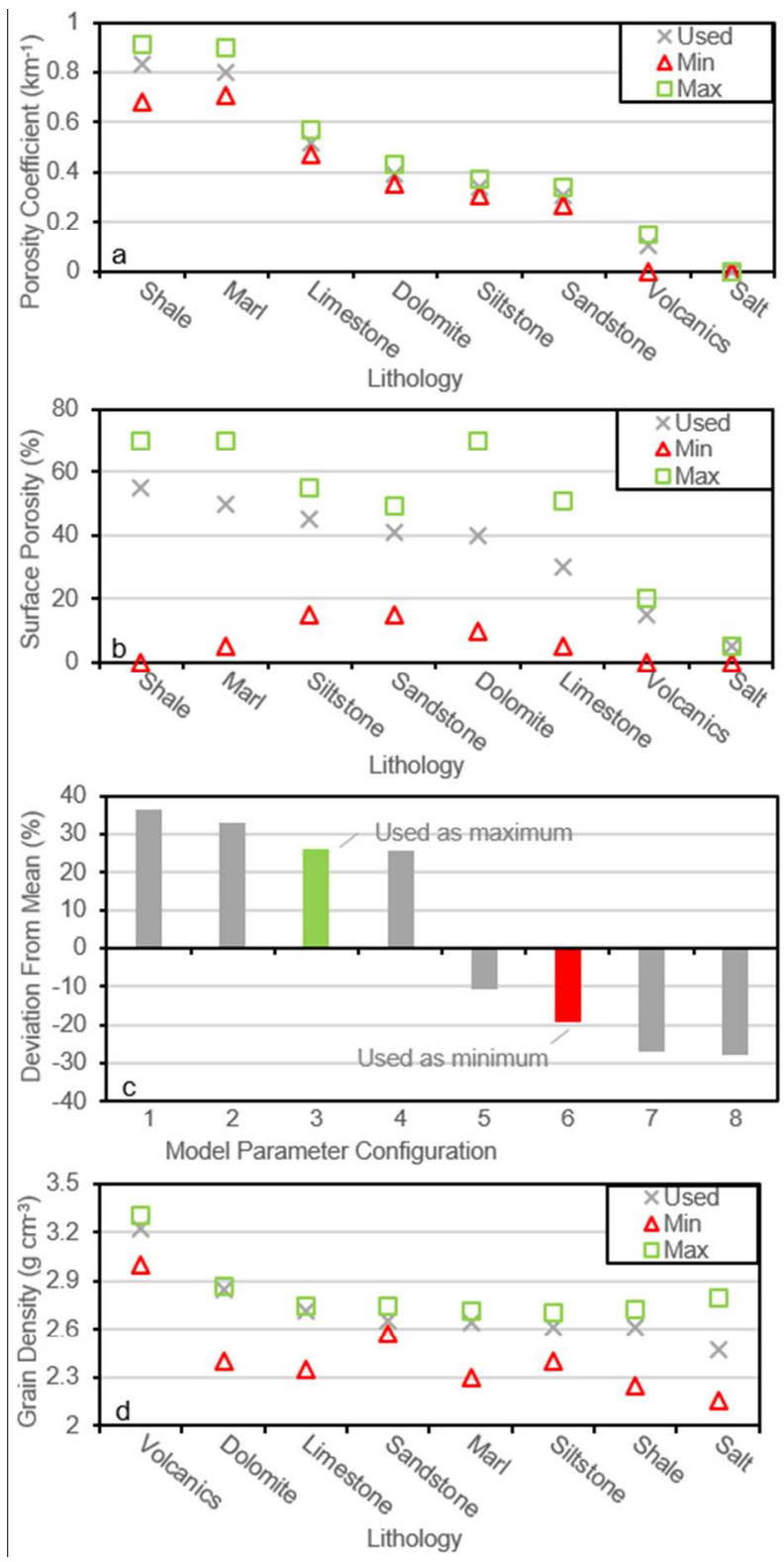

Input parameters of each lithology used (the lithology labelled salt, represents all evaporites) in the model along with maximum and minimum values that have been used to calculate the error of the model: (a) Porosity Coefficient (C); (b) Surface Porosity $(\Phi)$; (c) Grain density $(\rho)$. (d) Output variations of running the model under all possible input parameter configurations and the configurations used. $1=\operatorname{Min} \rho, M i n C$ and $\operatorname{Max} \Phi ; 2=\operatorname{Min} \rho$, Max $C$ and $\operatorname{Max} \Phi ; 3=\operatorname{Min} \rho$, Min $C$ and Min $\Phi ; 4=$ Min $\rho$, Max $C$ and Min $\Phi ; 5=$ Max $\rho$, Min $C$ and $\operatorname{Max} \Phi ; 6=\operatorname{Max} \rho$, Max $C$ and $\operatorname{Max} \Phi, 7=\operatorname{Max} \rho$, Min $C$ and Min $\Phi ; 8=\operatorname{Max} \rho$, Max $C$ and Min $\Phi$. 
(a) Tectonic subsidence (water loaded) of individual wells of the North Newfoundland block and their numerical mean. (b) Maximum and minimum errors for both subsidence and age on the North Newfoundland block mean curve.

$124 \times 183 \mathrm{~mm}(96 \times 96 \mathrm{DPI})$ 
(a) Tectonic subsidence (water loaded) of individual wells of the North Iberia block and their numerical mean. (b) Maximum and minimum errors for both subsidence and age on the North Iberian block mean curve.

$125 \times 183 \mathrm{~mm}(96 \times 96 \mathrm{DPI})$ 

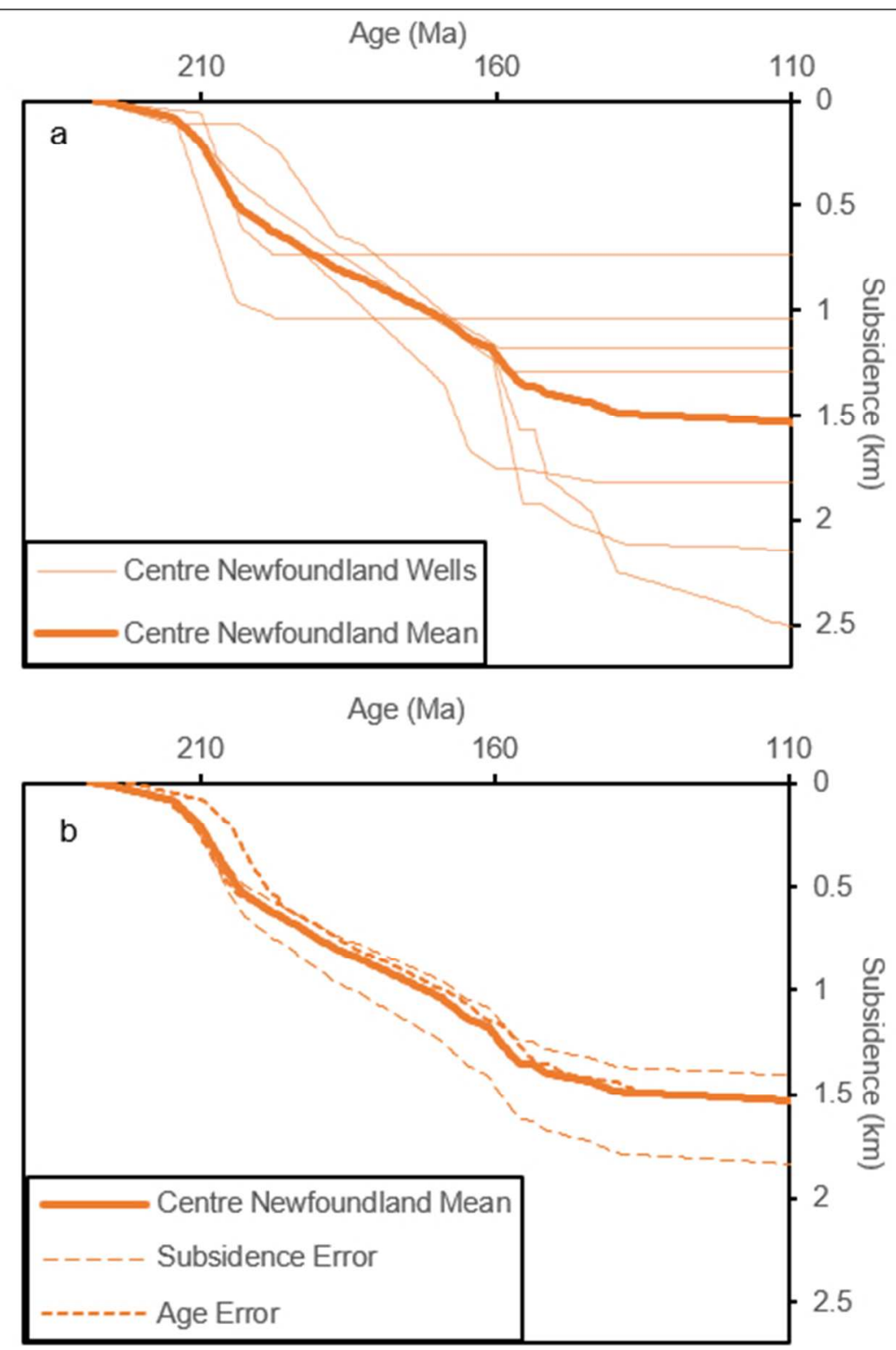

(a) Tectonic subsidence (water loaded) of individual wells of the Centre Newfoundland block and their numerical mean. (b) Maximum and minimum errors for both subsidence and age on the Centre Newfoundland block mean curve. 

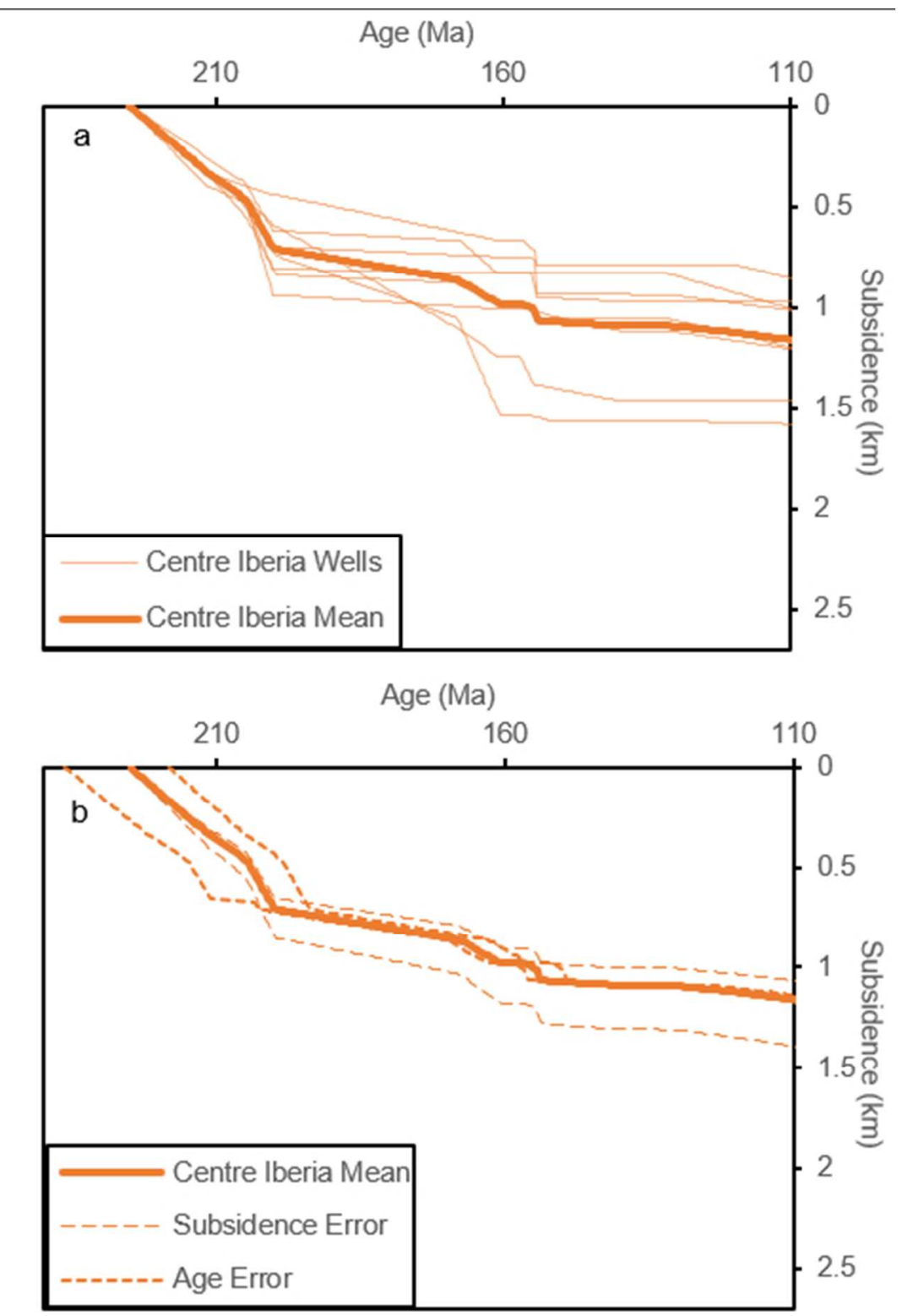

(a) Tectonic subsidence (water loaded) of individual wells of the Centre Iberia block and their numerical mean. (b) Maximum and minimum errors for both subsidence and age on the Centre Iberian block mean curve.

$125 \times 183 \mathrm{~mm}(96 \times 96 \mathrm{DPI})$ 


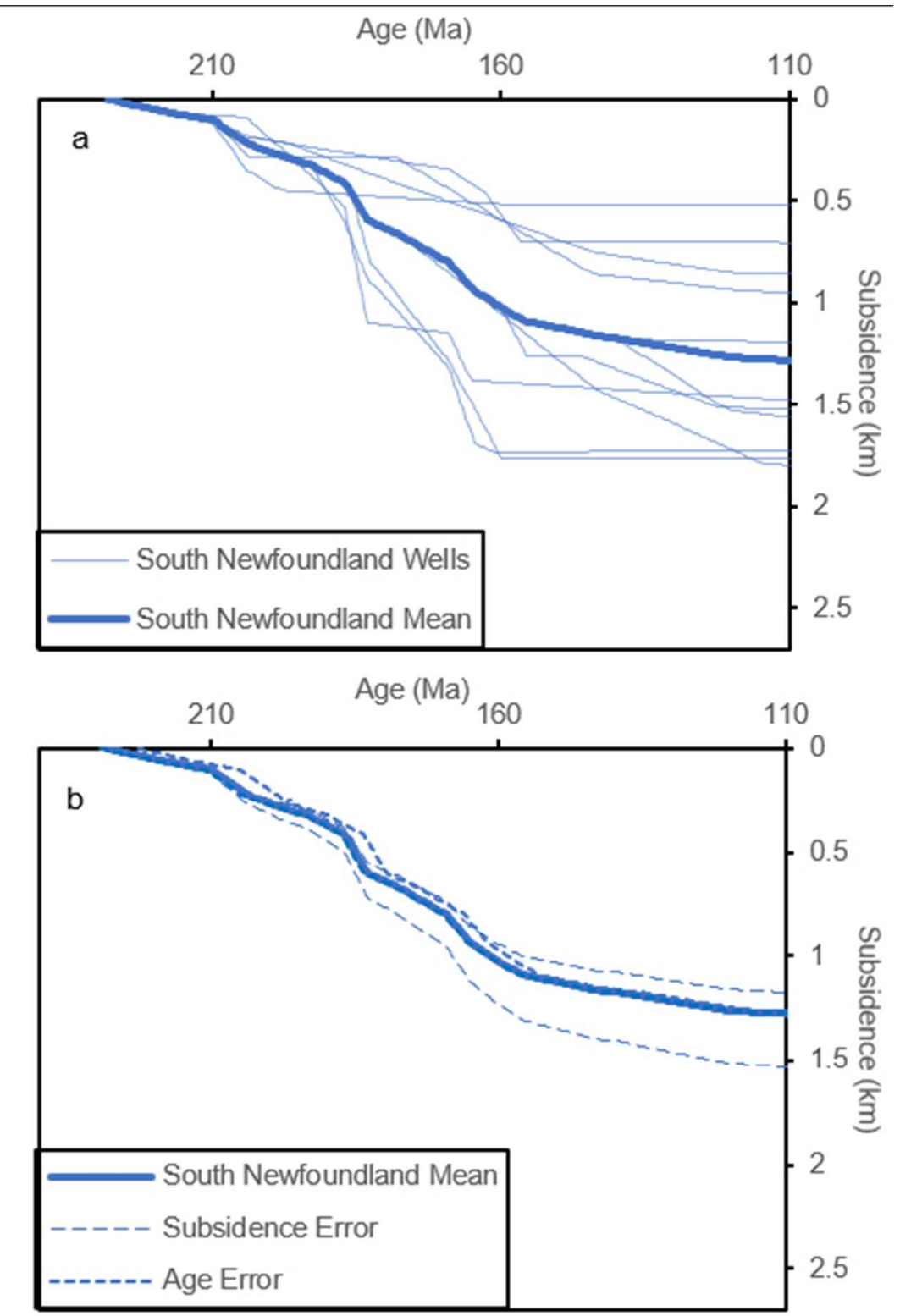

(a) Tectonic subsidence (water loaded) of individual wells of the South Newfoundland block and their numerical mean. (b) Maximum and minimum errors for both subsidence and age on the South Newfoundland block mean curve. 


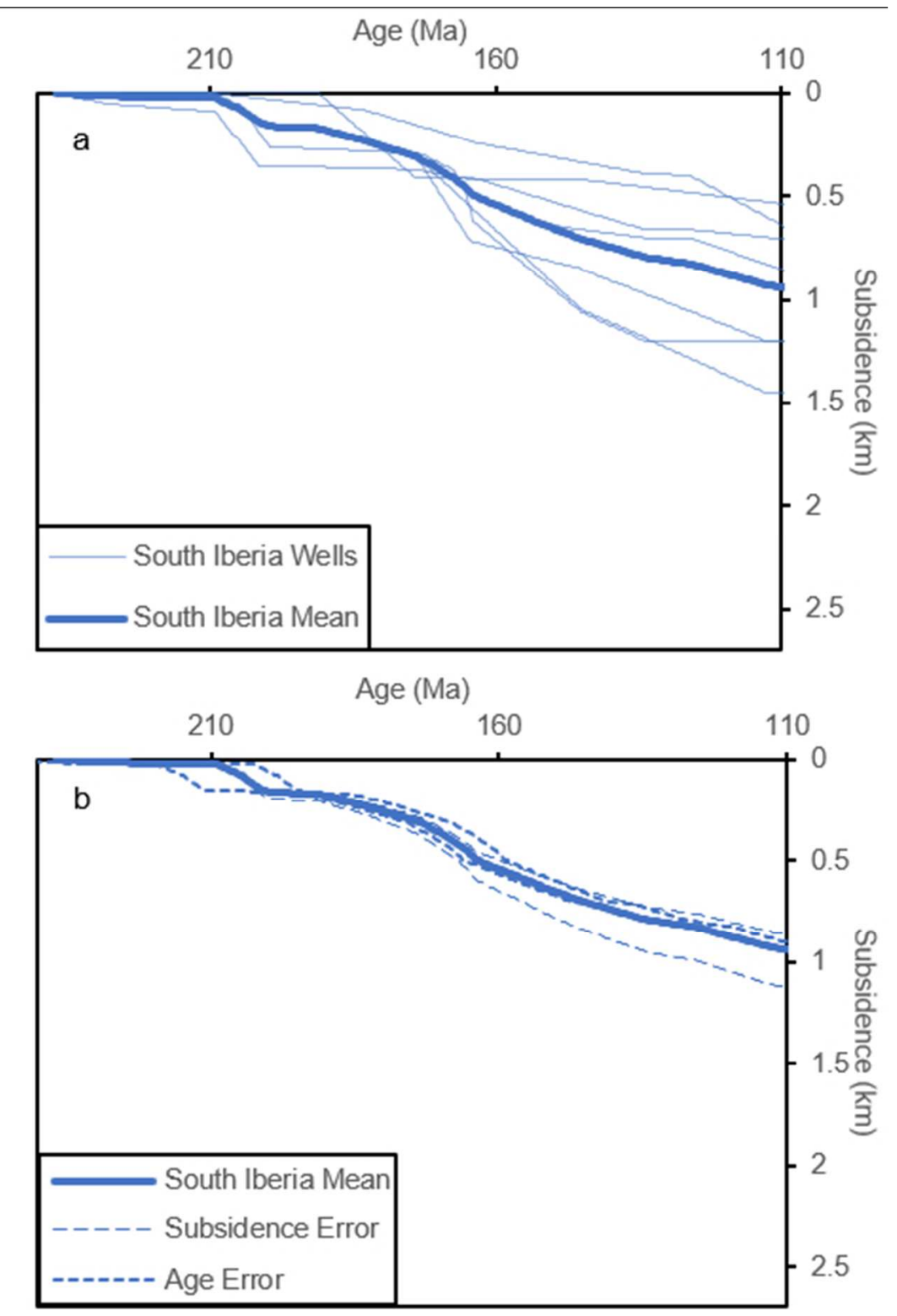

(a) Tectonic subsidence (water loaded) of individual wells of the South Iberia block and their numerical mean. (b) Maximum and minimum errors for both subsidence and age on the South Iberian block mean curve.

$124 \times 183 \mathrm{~mm}(96 \times 96 \mathrm{DPI})$ 

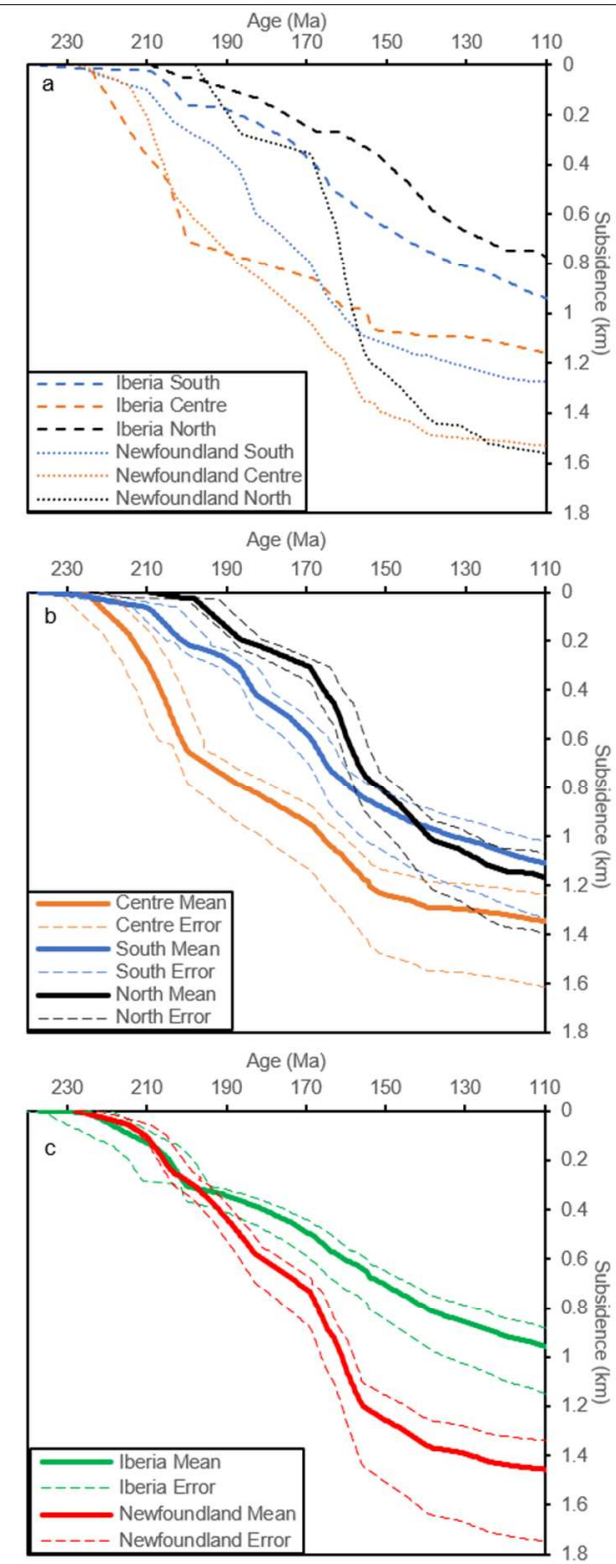

(a) Mean tectonic subsidence curves (water loaded) for each block on either side of the margin. (b) Mean tectonic subsidence curve (water loaded) for each segment of the margin and their associated error as an envelope. (c) Mean tectonic subsidence curve (water loaded) for each side of the margin as a whole and their associated error as an envelope. 